\title{
Melosira (Diatomeae) taxa from the Iguaçu River in southern Brazil
}

\author{
Margaret Seghetto Nardelli ${ }^{*}$, Priscila Izabel Tremarin ${ }^{2}$, Thelma Alvim Veiga Ludwig ${ }^{2}$ \& Norma Catarina Bueno ${ }^{1}$ \\ ${ }^{1}$ Universidade Estadual do Oeste do Paraná, Cascavel, PR, Brazil \\ ${ }^{2}$ Universidade Federal do Paraná, Departamento de Botânica, Centro Politécnico, Jardim das Américas, \\ Curitiba, PR, Brazil \\ *Corresponding author: Margaret Seghetto Nardelli, e-mail: margaretseghetto@hotmail.com
}

NARDELLI, M.S., TREMARIN, P.I., LUDWIG, T.A.V., BUENO, N.C. Melosira (Diatomeae) taxa from the Iguaçu

River in southern Brazil. Biota Neotropica. 16(4): e20160249. http://dx.doi.org/10.1590/1676-0611-BN-2016-0249

\begin{abstract}
The study of the genus Melosira in plankton samples from the lower Iguaçu River revealed the presence of four taxa: Melosira undulata (Ehrenberg) Kützing var. undulata, M. undulata var. normanni Arnott, M. varians C. Agardh and M. muscigena Iwahashi. We present illustrations of the frustules using light microscopy (LM), descriptions, and comments about the morphology of the four taxa. The analysis of Melosira muscigena under scanning electron microscopy revealed unprecedented details of the ultrastructure, such as the shape and distribution of the rimoportulae at the valve mantle. This is the first record of Melosira undulata var. undulata and the second of M. muscigena in Brazil.
\end{abstract}

Keywords: diatoms, southern Brazil, taxonomy, ultrastructure.

\section{Táxons de Melosira (Diatomeae) para o rio Iguaçu, sul do Brasil}

\begin{abstract}
Resumo: O estudo do gênero Melosira em amostras de plâncton do baixo rio Iguaçu revelou a presença de quatro táxons: Melosira undulata (Ehrenberg) Kützing var. undulata, M. undulata var. normanni Arnott, M. varians C. Agardh e $M$ muscigena Iwahashi. Apresentam-se ilustrações das frústulas usando microscopia óptica (MO), descrições e comentários sobre a morfologia dos quatro táxons. A análise de Melosira muscigena sob microscopia eletrônica de varredura revelou detalhes sem precedentes da ultraestrutura, como a forma e distribuição das rimopórtulas no manto da valva. Este é o primeiro registro de Melosira undulata var. undulata e o segundo de M. muscigena para o Brasil.
\end{abstract}

Palavras-chave: diatomáceas, sul do Brasil, taxonomia, ultraestrutura.

\section{Introduction}

Diatoms from the genus Melosira C. Agardh are characterized by cylindrical to subspherical frustule, usually united at the valve faces by mucilage pads and small irregular spines (Crawford 1975) in pairs or chains of three cells (Van Heurck 1896). The valve face can be flat or convex and may be bordered by a corona, with granules more or less developed, and a carina (collar-like structure) (Crawford 1975). The areolae are loculated with loculi open to the outside through small pores. The cingulum presents ligulate bands perforated by longitudinal rows of small pores (Round et al. 1990). Rimoportulae usually occur near the edge, scattered or grouped at the valve mantle (Round et al. 1990).

Previously, the genus Melosira included most of the centric diatoms that grew in chains with cells strongly connected by the valve face (Stoermer \& Julius 2003), accommodating a wide range of taxa gradually transferred to different genera, such as: Aulacoseira Thwaites, Paralia Heiberg, Orthoseira Thwaites, and Ellerbeckia Crawford (Round et al. 1990, Houk \& Klee 2007).

Melosira taxa occur in marine, brackish and freshwater benthic ecosystems (Round et al. 1990). Currently, there are at least five morphologically and ecologically heterogeneous groups within the genus: (1) marine and brackish taxa, this group includes the generic type, e.g., M. nummuloides C. Agardh and M. arctica Dickie, species with a very convex valve face with prominent carina and bands with fine poroids; (2) brackish, e.g. M. moniliformis (O.F. Müller) C. Agardh, with convex valve face and bands distinctively perforated by fine poroids, in partly radiating, mostly irregular short lines; (3) freshwater to slightly brackish, e.g., $M$. varians $\mathrm{C}$. Agardh and M. lineata (Dillwyn) C. Agardh, with dome-shaped valve face has smaller and much more delicate valves with inconspicuous ornamentation, difficult to see in LM. ; (4) recent fossil and freshwater, e.g. M. undulata (Ehrenberg) Kützing, M. muscigena Iwahashi (=M. ruttneri Hustedt), M. anastomosans Grunow, with distinct areolate valve face; (5) freshwater, epilithic, and epiphytic, e.g., M. dickiei (Thwaites) Kützing, with a cingulum composed of many narrow bands, forming internal valves (Crawford 1988, Houk \& Klee 2007).

Fifty-eight Melosira species are known (Novelo 2012), but the number of freshwater species are limited (Stoermer \& Julius 2003). In Brazil, 10 taxa have been recorded: marine taxa - M. borreri Greville, M. nummuloides, M. moniliformis, M. octogona Schmidt, M. setosa Greville and freshwater taxa- M. dickiei, M. lineata, M. muscigena Iwahashi (=M. ruttneri Hustedt), M. undulata var. normanni Arnott and M. varians (Rosa et al. 1994, Garcia 2009, Tremarin et al. 2009, Nardelli et al. 2014). Of these, six occurred in Paraná state: $M$. dickiei, M. lineata, M. nummuloides, M. varians, M. undulata var. normanni, and M. muscigena (Tremarin et al. 2009, Nardelli et al. 2014). 
Nardelli et al. (2014) have already recorded four species of Melosira in Iguaçu River - M. varians, M. muscigena, M. undulata var. normanni and Melosira sp.

Here, we presented a taxonomic survey of Melosira taxa for the Iguaçu River, showing unprecedented ultrastructural details of Melosira muscigena and the first citation of $M$. undulata var. undulata to Brazil.

\section{Material and Methods}

The Iguaçu River runs westward $1275 \mathrm{~km}$ from its source in the Serra do Mar to its confluence with the Paraná River (Paraná 2010). Considered a large river, part of the river is located in Iguaçu National Park, a protected area important for its great biodiversity (Paraná 2010).

Station 1 (S1) is located upstream of the falls $\left(25^{\circ} 39^{\prime} 12,8^{\prime \prime} \mathrm{S}\right.$ and $54^{\circ} 25^{\prime} 34,0^{\prime \prime} \mathrm{W}$ ), where the river is wider, with variable depth from $1.4 \mathrm{~m}$ to $3.0 \mathrm{~m}$. The station was classified as oligo-mesotrophic for the sampling period, with maximum and minimum values according the Table 1 (Nardelli et al. 2016).

Station 2 (S2) is downstream from the falls $\left(25^{\circ} 38^{\prime} 55,4^{\prime \prime} \mathrm{S}\right.$ and $\left.54^{\circ} 27^{\prime} 31,0^{\prime \prime} \mathrm{W}\right)$. In this region, the river is narrower, deeper (11.7 to $\left.27.4 \mathrm{~m}\right)$ and flows faster than at Station 1. Station 2 was classified as ultra-oligotrophic to oligotrophic for the sampling period, with maximum and minimum chemical and physical values according the Table 1 (Nardelli et al. 2016).

Table 1. Maximum and minimum chemical and physical values in Station 1 and Station 2. Water temperature $\left(\mathrm{T}^{\circ} \mathrm{C}\right) ; \mathrm{pH}$; Dissolved oxygen (DO mg.L-1 $)$; Biochemica Oxygen Demand (BOD mg. $\mathrm{L}^{-1}$ ); Chemical Oxygen Demand (COD mg.L-1 $\mathrm{L}^{-1}$; Electrical Conductivity (Cond $\left.\mu \mathrm{S} . \mathrm{cm}^{-1}\right)$; Secchi Transparency (SD m); Turbidity (NTU); Ammonium (NH4 $\mu \mathrm{g} . \mathrm{L}^{-1}$ ); Total Nitrogen (TN $\mu \mathrm{g} . \mathrm{L}^{-1}$ ); Nitrate (NO3 $\mu \mathrm{g} . \mathrm{L}^{-1}$ ); Total phosphorus (TP $\mu$ g. $\mathrm{L}^{-1}$ ) (Nardelli et al. 2016).

\begin{tabular}{|c|c|c|c|c|}
\hline \multirow{2}{*}{\begin{tabular}{|c|} 
Stations \\
Parameters
\end{tabular}} & \multicolumn{2}{|c|}{ Station 1} & \multicolumn{2}{|c|}{ Station 2} \\
\hline & Min & Max & Min & Max \\
\hline Water $\mathrm{T}^{\circ} \mathrm{C}$ & 15.5 & 28.6 & 15.9 & 28.8 \\
\hline $\mathrm{pH}$ & 6.1 & 8.7 & 5.9 & 8.3 \\
\hline DO mg. $L^{-1}$ & 6.4 & 12.2 & 6.6 & 13.1 \\
\hline BOD mg. $L^{-1}$ & 0.9 & 11.4 & 1.8 & 13.9 \\
\hline COD mg.L L $^{-1}$ & 6.8 & 21.6 & 4.7 & 25.9 \\
\hline Cond $\mu$ S.cm ${ }^{-1}$ & 32.8 & 105.0 & 34.0 & 87.0 \\
\hline $\mathrm{SD} \mathrm{m}$ & 0.9 & 3.6 & 0.7 & 3.6 \\
\hline NTU & 2.0 & 26.1 & 2.8 & 23.2 \\
\hline $\mathrm{NH}_{4}^{+} \mu \mathrm{g} \cdot \mathrm{L}^{-1}$ & 0.8 & 123.2 & 0.4 & 70.4 \\
\hline $\mathrm{TN} \mu \mathrm{g} . \mathrm{L}^{-1}$ & 100.0 & 500.0 & 110.0 & 500.0 \\
\hline $\mathrm{NO}_{3}^{-} \mu \mathrm{g} \cdot \mathrm{L}^{-1}$ & 100.0 & 2140.0 & 100.0 & 1730.0 \\
\hline $\mathrm{TP} \mu \mathrm{g} . \mathrm{L}^{-1}$ & 20.0 & 450.0 & 50.0 & 390.0 \\
\hline
\end{tabular}

Monthly collections were performed between September 2010 and September 2011, from the subsurface water of the river with a phytoplankton net. Samples were cleaned according to the Simonsen (1974) method modified by Moreira-Filho \& Valente-Moreira (1981). Permanent slides were mounted with $\operatorname{Naphrax}^{\circledR}(\mathrm{RI}=1.73)$ and analyzed with an Olympus ${ }^{\circledR}$ BX60 microscope. Images were obtained with an Olympus DP71 digital camera. The slides are deposited in the herbarium of the Universidade Estadual do Oeste do Paraná (UNOP-Algae, Western Paraná State University), Cascavel campus (Table 2).

Part of the oxidized material was placed on aluminum stubs and sputter-coated with gold in a Balzers SCD 030 at $1 \mathrm{kV}$ for $5 \mathrm{~min}$. Scanning electron microscopy (SEM) analysis was performed in a JEOL JSM $6360 \mathrm{LV}$ microscope operating at $15 \mathrm{kV}$ and $8 \mathrm{~mm}$ working distance. The terminology used in the species descriptions follows Round et al. (1990) and Houk \& Klee (2007).

\section{Results and Discussion}

Coscinodiscophyceae Round \& Crawford in Round et al. 1990

Melosirales Crawford 1990 in Round et al. 1990

Melosiraceae Kützing 1844

Melosira C. Agardh 1824

Melosira muscigena Iwahashi. Journal of Japanese Botany, 12(2): 121-127, p.121, fig.17. 1936.

Synonym: Melosira ruttneri Hustedt. Archiv für Hydrobiologie 15: 140-141, pl. 9, fig. 11-16. 1937.

LM observations. Cylindrical frustules, with thick wall of uneven structure forming two layers, the external view cylindrical and the internal view more or less elliptical. Valve mantle formed with a reticulated pattern in polygonal chambers, decreasing toward collar. Circular valve view, reticulated striation pattern, composed of polygonal areolae decreasing in diameter toward the center, changing to radial rows of small pattern, scored lengthwise, hyaline central area. Cells solitary or joined by the valve face, forming pairs or short chains of three cells. Mantle height: 14.3-15.5 $\mu \mathrm{m}$; diameter: 15.7-27.9 $\mu \mathrm{m}$; 19-21 striae in $10 \mu \mathrm{m}$ (Figures 1-10).

SEM observations. Flat valve face with short marginal spines. Rimoportulae scattered on the valve face and disposed in a ring around the mantle, not equidistant from each other. Rimoportula with external openings rounded or elongated, $0.5 \mu \mathrm{m}$ in diameter, and internally sessile. Collar with short pervalvar wrinkles at the valve margin, and often oblique. Connective bands open, ornamented by delicate striae, 9-10 per $1 \mu \mathrm{m}$, composed by rounded pores, $10-11$ per $1 \mu \mathrm{m}$. Prominent ligule and rounded antiligule. Fimbriate valvocopula and pleura thinner than the other bands (Figures 11-18).

Table 2. Herbarium data from plankton sampled in Station 1 (S1) and Station 2 (S2).

\begin{tabular}{|c|c|c|c|}
\hline Collection date & $\begin{array}{c}\text { S1 } \\
\text { UNOP-Algae }\end{array}$ & $\begin{array}{c}\text { S2 } \\
\text { UNOP-Algae }\end{array}$ & Collector(s) \\
\hline September 2010 & 3161 & 3156 & M.S. Nardelli $n .11,12$, N.C. Bueno s.n. \\
\hline October 2010 & 3225 & 3213 & M.S. Nardelli $n .14,18$, N.C. Bueno s.n. \\
\hline December 2010 & 3342 & 3338 & M.S. Nardelli $n .21,25$, N.C.Bueno s.n. \\
\hline January 2011 & 3412 & 3408 & M.S. Nardelli $n$. 31, 35, N.C. Bueno s.n. \\
\hline February 2011 & 3471 & 3467 & M.S. Nardelli $n .38,42$, N.C. Bueno s.n. \\
\hline March 2011 & 3536 & 3530 & M.S. Nardelli $n .45,51$, N.C. Bueno s.n. \\
\hline April 2011 & 3606 & 3601 & M.S. Nardelli $n .55,60$, N.C. Bueno s.n. \\
\hline May 2011 & 3680 & 3670 & M.S. Nardelli $n .68,74$, N.C. Bueno s.n. \\
\hline June 2011 & 3714 & 3709 & M.S. Nardelli $n .80,85$, N.C. Bueno s.n. \\
\hline July 2011 & 3758 & 3753 & M.S. Nardelli $n .92,97$, N.C. Bueno s.n. \\
\hline August 2011 & 3775 & 3770 & M.S. Nardelli $n .101,106$, N.C. Bueno s.n. \\
\hline September 2011 & 3784 & 3779 & M.S. Nardelli $n .110,115$, N.C. Bueno s.n. \\
\hline
\end{tabular}




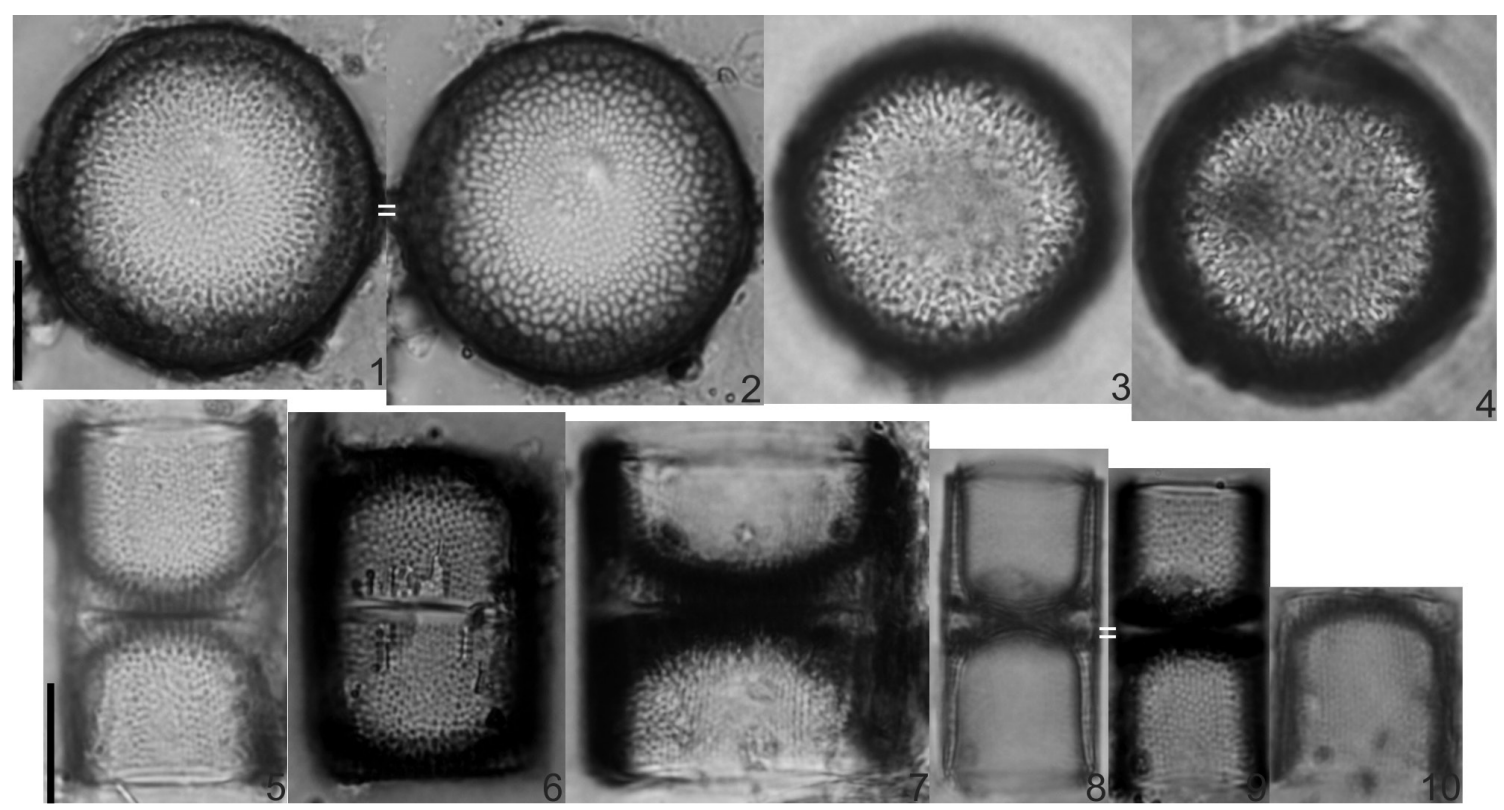

Figures 1-10. Melosira muscigena, LM. Figures 1-4. Valve view. Figures 5-10. Girdle view. Scales: $10 \mu \mathrm{m}$.

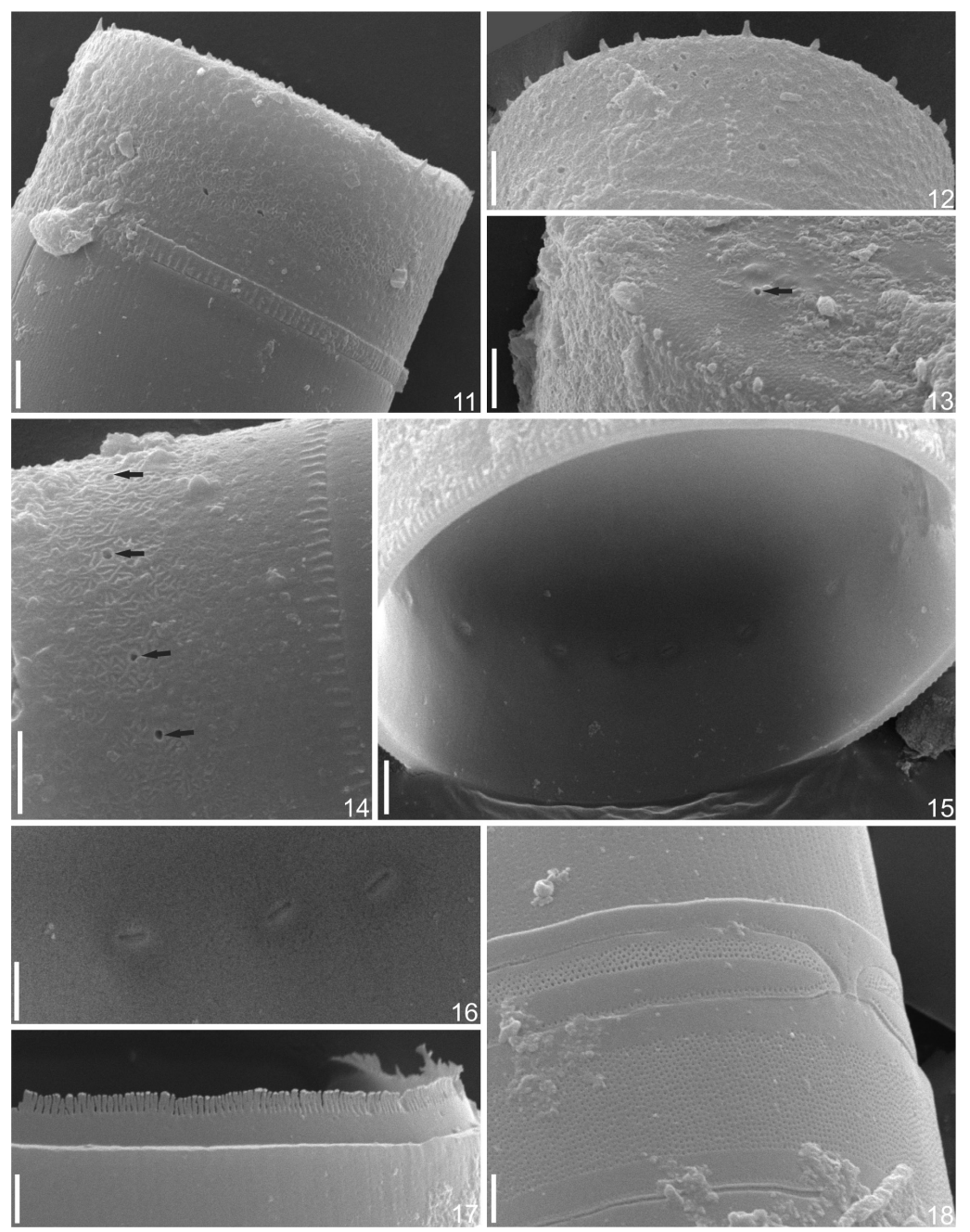

Figures 11-18. Melosira muscigena, SEM. Figure 11. Girdle view. Figure 12. Marginal spines located in the valve face/mantle junction. Figure 13. External rimoportula opening in the valve face (arrow). Figure 14. External rimoportula openings in the mantle (arrows). Figure 15. Internal rimoportula openings in the mantle. Figure 16. Detail of internal rimoportula openings. Figure 17. Fimbriate valvocopula. Figure 18. Detail of ligulate pleura and cingulum bands perforated by porous. Scales: $2 \mu \mathrm{m}$ (Figs 11-15), $1 \mu \mathrm{m}$ (Figs 16-18). 
Comments. This is the first ultrastructure documentation of a brazilian population of Melosira muscigena. Analysis via SEM revealed unprecedented details of the ultrastructure, such as the shape and distribution of the rimoportulae at the valve mantle. The species was recorded by Koide (1987), as M. ruttneri, by Houk \& Klee (2007) and Nardelli et al. (2014). Koide (1987) compared individuals identified as M. ruttneri from Japan (pl. 1, figures 1-7; diameter: 7-33 $\mu \mathrm{m}$; mantle height: 5-25 $\mu \mathrm{m}$ ) with the type material illustrations present by Iwahashi (1936) of M. muscigena (diameter: 16-33 $\mu \mathrm{m}$; mantle height: $12-20 \mu \mathrm{m}$ ) and verified that it was the same taxon. The only difference found in the Hustedt (1937) and Iwahashi (1936) descriptions was regarding the presence or absence of thin spines on the rim of the valve face. The first describes the spines as not being well distinguished, and the latter makes no mention of them. As the M. muscigena name is older, it has priority over M. ruttneri.

We suggested the investigation of Melosira muscigena and Melosira ruttneri type materials since they were originally described based on optically limited characteristics. Also the original illustrations are uninformative. The two taxa are ambiguous, showing many similarities in their morphology. The frustule ultrastructure would properly ascertain other morphologically diagnostic features between the species.

Melosira muscigena is morphologically similar to M. anastomosans Grunow in the reticulate pattern of the valve face but differs in the mantle outline, which is rounded and more similar to M. undulata (Houk \& Klee 2007).

Houk \& Klee (2007) describe M. ruttneri as rare in waterfalls, springs, and streams. It is frequently found in moss, and also a good indicator of alkaline waters (Koide 1987). However, in the present study, the species was found in the Iguaçu River, a place of flow and large water falls.

Occurrence in samples: (UNOP-Algae, Herbarium accession numbers) 3213, 3606, 3709, 3753, 3758, 3770, 3784.

Melosira undulata (Ehrenberg) Kützing var. undulata. Bacillarien, p.54, 1844.

LM observations. Cylindrical frustules (Figure 19), usually solitary or united in pairs or short chains, valves wider than higher, internally
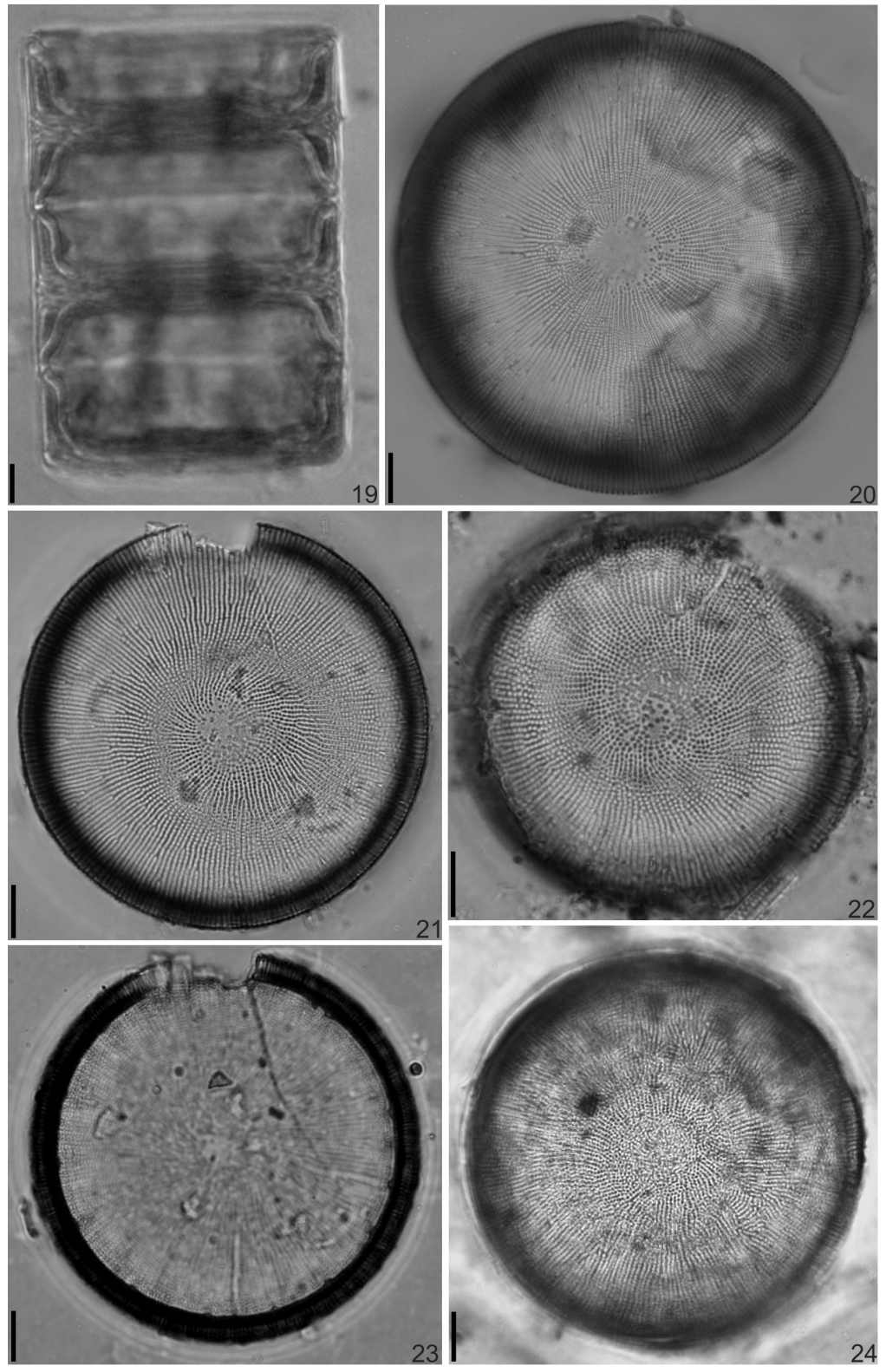

Figures 19-20. Melosira undulata var. undulata, LM. Figure 19. Frustules in girdle view showing undulate inner mantle surface. Figure 20. Valve view. Figures 21-24. Valve view of Melosira undulata var. normanii, LM. Figure 23. Note the position of rimoportulae in the internal valve margin. Scales: $10 \mu \mathrm{m}$. 
constricted at the mantle midregion. Internal margin the of valve face with polygonal circumference and areolae disposed in radial rows which do not reach the valve center, forming a small hyaline central area (Figure 20). Mantle height: 21.5-32.0 $\mu \mathrm{m}$; diameter: 93.5-94.0 $\mu \mathrm{m}$; 10-11 striae in $10 \mu \mathrm{m}$ on the valve face; $17-18$ areolae in $10 \mu \mathrm{m}$ on the valve face; 10 internal projections on the wall.

Comments. Krammer \& Lange-Bertalot (1991) describe M. undulata var. undulata as presenting a rounded valve, with internal margin the of valve face with polygonal circumference different from the internal rounded shape of M. undulata var. normanii Arnott. Ferguson Wood et al. (1959) described individuals with polygonal morphology with six to twelve internal projections, however they did not illustrate specimens with these characteristics. Such internal projections are consistent with the sessile rimoportulae present in the valve mantle. Rimoportulae may also be found in the central region of the valve mantle (Bahls 2012).

The population here studied exhibit greater diameter than the one recorded by Houk (2003), 16-80 $\mu \mathrm{m}$, and Bahls (2012), 30-81 $\mu \mathrm{m}$. However, the other features of the taxon are coincident.

Melosira undulata var. undulata is an epilithic species occurring in circumneutral, oligohalobous (Foged 1976), and oligotrophic (Carter et al. 2006) environments. The species is frequently found in small arctic lakes and lagoons and with freshwater diatomites (Hustedt 1937, Mahood et al. 1984, McIntire et al. 1994, Stoermer \& Julius 2003). It has also been detected in sediments, as well as in the plankton of tropical areas (Manguin 1949, Sovereign 1958, Ferguson Wood et al. 1959, Germain 1981, Huang, 1982, Krammer \& Lange-Bertalot 1991, Li et al. 2010). In addition to those, Takano (1967) found M. undulata var. undulata in brackish water in Abashiri, Japan. This is the first record of M. undulata var. undulata in Brazilian rivers.

Occurrence in samples: (UNOP-Algae, Herbarium accession numbers) 3156.

Melosira undulata var. normanii Arnott. In Van Heurck, Synopsis, p. 90 , f. 7.1882.
LM observations. Cylindrical frustules, united in pairs or short chains. Rounded valve face with rounded internal wall, ornamented with areolate striae in radial rows, sometimes ramified and with a spiral arrangement in the central region. Diameter: $42.3-89.4 \mu \mathrm{m} ; 10-11$ striae in $10 \mu \mathrm{m}$ on the valve face; $12-14$ areolae in $10 \mu \mathrm{m}$ on the valve face (Figures $21-24$ ).

Comments. Melosira undulata var. normanii differs from the typical variety by the spiral arrangement of central striae on the valve face as also the different internal margin the valve face described above (Krammer \& Lange-Bertalot 1991, Brassac et al. 1999). Our study also found a smaller number of areolae $(12-14$ in $10 \mu \mathrm{m})$ in the var. normanii compared to the typical variety $(17-18$ in $10 \mu \mathrm{m})$.

Krammer \& Lange-Bertalot (1991) comment that the species is taxonomically closer to the genus Orthoseira Thwaites due the structure of valve surface, requiring a more detailed taxonomic study. However, Garcia (2009) did a taxonomic comparison of Melosira undulata var. normanii with the genera Orthoseira, Paralia Heiberg, Ellerbeckia Crawford, Podosira Ehrenberg, and Hyalodiscus Ehrenberg and concluded that the species features are in accordance with the genus Melosira.

Records of Melosira undulata var. normanii from Brazil: in Rio Grande do Sul State, plankton from a brackish lagoon (Rosa et al. 1994), sand from Guaíba river, and plankton from Emboaba lagoon (Garcia 2009); in Paraná State, plankton from Iguaçu river (Brassac et al. 1999, Nardelli et al. 2014); and in Pernambuco State, estuarine plankton from Barra da Jangada (Branco 2007).

Occurrence in samples: (UNOP-Algae, Herbarium accession numbers) 3156, 3408, 3471, 3601, 3770.

Melosira varians C. Agardh. Flora oder Botanische Zeitung, 10:628. 1827.

LM observations. Cylindrical frustules forming straight chains connected to the valve face through small marginal spines (Figures 25-33). Circular valve face ornamented by delicate and inconspicuous areolae (Figures 34 and 35). Mantle height: 24.6-40.0 $\mu \mathrm{m}$; diameter: 18.9-50.7 $\mu \mathrm{m}$.

Comments. Melosira varians occurs mainly in alkaline conditions ( $\mathrm{pH} 7-8.5)$, in oligotrophic to heterotrophic environments, with moderate
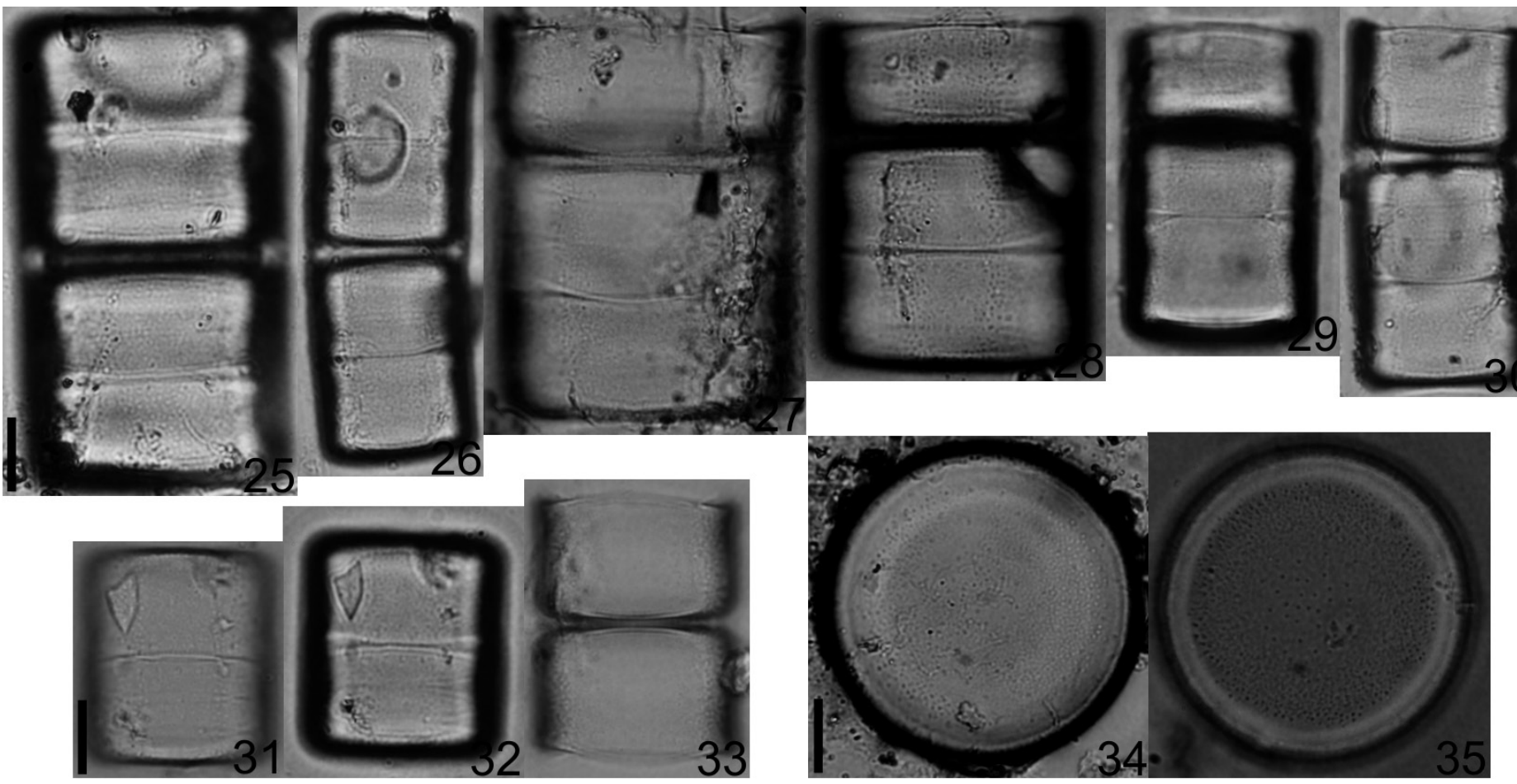

Figures 25-35. Melosira varians, LM. Figures 25-33. Girdle view. Figures 34-35. Valve view. Scales: $10 \mu \mathrm{m}$. 
oxygen, and requires periodically high levels of nitrogen. Occurs mainly in water bodies, but it is also regularly found in humid environments (Soltanpour-Gargari et al. 2011).

Melosira varians is a very common species in freshwater, occurring in considerable abundance in streams and lakes, naturally eutrophic to polluted, throughout North America (Stoermer \& Julius 2003). It is also very common in Brazilian waters, with more than 30 records from the Paraná (Tremarin et al. 2009) as opposed to M. undulata and M. muscigena Iwahashi, which have few taxonomic records around the world.

Occurrence in samples: (UNOP-Algae, Herbarium accession numbers) 3156, 3161, 3213, 3225, 3338, 3342, 3408, 3412, 3467, 3471, 3530, 3536, 3601, 3606, 3670, 3680, 3709, 3714, 3753, 3758, 3770, 3775, 3779, 3784.

\section{Conclusion}

This is an important study about the knowledge of Melosira diversity in Brazil and taxonomy of the genus as a whole. Melosira undulata var. normanii and $M$. mucigena are taxa with restricted distribution, which have few taxonomic records around the world. We did not find enough individuals in the samples to analyze in electron microscopy the taxon M. undulata var. normanni as also the typical variety, for highlighting the differences between both. There is a need for new studies under scanning electron microscopy, with a larger number of individuals, in order to discuss details of the ultrastructure.

\section{Acknowledgments}

Thanks to the Coordenação de Aperfeiçoamento Pessoal de Nível Superior - CAPES for the scholarship awarded to the first author; and to the staff of Electron Microscopy Center of Universidade Federal do Paraná for their SEM technical assistance, Instituto Chico Mendes de Conservação da Biodiversidade (ICMBio) for providing the license to this research and to the staff of Iguaçu National Park for supporting the sampling. NCB and TAVL are grateful for CNPq grants (307196/2013-5 and 308332/2013-0).

\section{References}

BAHLS, L. 2012. Melosira undulata. In Diatoms of the United States. http:// westerndiatoms.colorado.edu/taxa/species/melosira_undulata. 01 Jun. 2016 (Date of last successful access).

BRANCO, E.S. 2007. Influência das variáveis ambientais na comunidade fitoplanctônica estuarina. Recife: Ed. Universitária da UFPE.

BRASSAC, N.M., ATAB, D.R., LANDUCCI, M., VISINONI, N.D. \& LUDWIG, T.V. 1999. Diatomáceas cêntricas de rios na região de abrangência da usina hidrelétrica de Salto Caxias, PR (Bacia do Iguaçu). Acta Botanica Brasilica 13(3): 277-289.

CARTER, D.T., ELY, L.L., O’CONNOR, J.E. \& FENTON, C.R. 2006. Late Pleistocene outburst flooding from pluvial Lake Alvord into the Owyhee River, Oregon. Geomorphology 75: 346-367. doi:10.1016/j.geomorph.2005.07.023.

CRAWFORD, R.M. 1975. The frustule of the initial cels of some species of the diatom genus Melosira C. Agardh. Nova Hedwigia 53: 37-50.

CRAWFORD, R.M. 1988. A reconsideration of Melosira arenaria and M. teres; resulting in a proposed new genus Ellerbeckia. In: Round FE. (ed.) Algae and the aquatic environment. Biopress, Bristol. p. 413-433.

FERGUSON WOOD, E.J., CROSBY, L.H. \& CASSIE, V. 1959. Studies on Australian and New Zealand Diatoms. III- Descriptions of Further Discoid Species. Transactions of the Royal Society of New Zealand 87: 211-219.

FOGED, N. 1976. Freshwater diatoms in Sri Lanka (Ceylon). Bibliotheca Phycologica 23: $1-113$

GARCIA, M. 2009. Morphology and Taxonomy of Melosira undulata (Ehrenb.) Kütz. var. normanii Arn. (Bacillariophyta) from Rio Grande do Sul, Brazil. Diatom 25: 37-44.
GERMAIN, H. 1981. Flore des diatomées - Diatomophycées- eaux douces et saumâtres du Massif Armoricain et des contrées voisines d'Europe occidentale. Collection “Faunes et Flores Actuelles".Paris. Société Nouvelle des Editions Boubée.

HOUK, V. 2003. Atlas of freshwater centric diatoms with a brief key and descriptions. Part I., Melosiraceae, Orthoseiraceae, Paraliaceae and Aulacoseiraceae. In: Poulícková, A. (Ed.). Czech Phycology. Supplement 1: 1-111.

HOUK, V. \& KLEE, R. 2007. Atlas of freshwater centric diatoms with a brief key and descriptions. Part II. Melosiraceae and Aulacoseiraceae (Supplement to Part I). Fottea 7: 85-255.

HUANG, C.Y. 1982. Some new information on microstructures of Melosira varians, M. jurgensi and M. undulata. Acta Botanica Sinica 24: 524-530.

HUSTEDT, F. 1937. Systematische und ökologische Untersuchungen über die Diatomeen-Flora von Java, Bali und Sumatra nach dem Material der Deutschen Limnologischen Sunda-Expedition. "Tropische Binnengewässer, Band VII". Archives für Hydrobiologie, Supplement 15: 131-177.

IWAHASHI, Y. 1936. Freshwater Centricae in Japan. V. Journal of Japanese Botany 12: $121-127$.

KOIDE, G. 1987. Diatom community attached to the rock of stone chamber of Ishibutai ancient tomb in Asuka Town, Nara Prefecture, Japan. Diatom 3:109-116.

KRAMMER, K. \& LANGE-BERTALOT, H. 1991. Süßwasserflora von Mitteleuropa. Band 2 (Bacillariophyceae) Teil 3 (Centrales, Fragilariaceae, Eunotiaceae). Gustav Fischer Verlag. Stuttgart 1: 1-576.

LI, Y.M., FERGUSON, D.K., WANG, Y.F. \& LI, C.S. 2010. Paleoenvironmental inferences from diatom assemblagesof the middle Miocene Shanwang Formation, Shandong, China. Journal of Paleolimnology 43:799-814. doi:10.1007/s10933009-9369-9.

MAHOOD, A.D., THOMSON, R.D. \& GOLDMAN, C.R. 1984. Centric diatoms of Lake Tahoe. Great Basin Naturalist 44: 83-98.

MANGUIN, E. 1949. Contribution à la connaissance des diatomées fossiles des dépots lacustres de l'Ankaratra (Madagascar). Annales géologiques du Service des Mines 18: 85-115.

MCINTIRE, C.D., PHINNEY, H.K., LARSN, G.L. \& BUKTENICA, M. 1994. Vertical distribution of a deep-water moss and associated epiphytes in Crater Lake, Oregon. Northwest Science 68: 11-21.

MOREIRA-FILHO, H. \& VALENTE-MOREIRA, I.M. 1981. Avaliação taxonômica e ecológica das diatomáceas (Bacillariophyceae) epífitas em algas pluricelulares obtidas nos litorais dos Estados do Paraná, Santa Catarina e São Paulo. Boletim do Museu Botânico Municipal 47: 1-17.

NARDELLI, M.S., BUENO, N.C., LUDWIG, T.A.V., TREMARIN, P.I. \& BARTOZEK, E.C.R. 2014. Coscinodiscophyceae and Fragilariophyceae (Diatomeae) in the Iguaçu River, Paraná, Brazil. Acta Botanica Brasilica 28: 127-140. doi: org/10.1590/S0102-33062014000100013

NARDELLI, M.S., BUENO N.C., LUDWIG, T.A.V. \& GUIMARÃES, T.B. 2016 Structure and dynamics of the planktonic diatom community in the Iguassu River, Paraná State, Brazil. Brazilian Journal Biology 76: (2) 374-386. doi: org/10.1590/1519-6984.16114

NOVELO, E. 2012. Flora del Valle de Tehuacán-Cuicatlán. Universidad Naciona Autónoma de México, Instituto de Biología. Departamento de Botánica. Fascículo 102. Bacillariophyta Hustedt.

PARANÁ. 2010. Instituto das Águas do Paraná (ÁguasParaná). http://www. aguasparana.pr.gov.br/modules/conteudo/conteudo. php?conteudo=38.09 apr. 2011(Date of last successful access).

ROSA, Z.M., WERNER, V.R.D. \& ACROCE, L. 1994. Diatomáceas da Lagoa de Tramandaí e da Lagoa do Armazém, Rio Grande do Sul, Brasil: III -Ordem Centrales. Iheringia. Série Botânica 48: 29-55.

ROUND, F.E., CRAWFORD, R.M. \& MANN, D.G. 1990 (This digitally printed version 2007). The diatoms: biology $\&$ morphology of the genera. Cambridge, Cambridge University Press.

SIMONSEN, R. 1974. The diatom plankton of the Indian Ocean Expedition of R/V "Meteor", 1964-65 “Meteor" Forschungsergbnisse, Reihe D-Biologie 19: 1-66.

SOVEREIGN, H.E. 1958. The diatoms of Crater Lake, Oregon. Transactions of the American Microscopical Society 77: 96-134.

SOLTANPOUR-GARGARI, A., LODENIUS, M. \& HINZ, F. 2011. Epilitic diatoms (Bacillariophyceae) from streams in Ramsar, Iran. Acta Botanica Croatica 70: 167-190. 
STOERMER, E.F. \& JULIUS, M.L. 2003. Centric diatoms. In: Wehr, JD, Sheath, RG. (eds). Freshwater algae of North America: ecology and classification. San Diego, Academic Press. p. 559-594.

TAKANO, H. 1967. Notes on marine littoral diatoms from Japan III. Bulletin of the Tokai Regional Fisheries Research Laboratory 49: 1-9.

TREMARIN, P.I., FREIRE, E.G., BERTOLLI, L.M. \& LUDWIG, T.A.V. 2009. Catálogo das diatomáceas (Ochrophyta-Diatomeae) continentais do estado do Paraná. Iheringia, Série Botânica 64: 79-107.
VAN HEURCK, H. 1896. A treatise on the diatomaceae. Illustrated by about 2000 figures. Translated by WYNNE, E. \& BAXTER, F.R.M.S. London: William Wesley \& Son, 28, Essex Street, Strand, WC.

Received: $16 / 08 / 2016$

Revised: 12/11/2016

Accepted: 16/11/2016 